\title{
NOTES
}

\section{THE STATUTE OF LIMITATIONS IN CRIMINAL LAW: A PENETRABLE BARRIER TO PROSECUTION}

A criminal statute of limitations, in barring prosecution after the passage of a stated period of time, is an act of grace ${ }^{1}$ representing a legislative determination that the purposes of the criminal law may best be served under some circumstances by limiting the power to proceed against an alleged criminal. Absent such a statute a criminal act may be the basis of a prosecution at any time after its commission. ${ }^{2}$ Since law enforcement ordinarily requires the prosecution of those who commit criminal acts, why are such legislative limitations imposed? If there are valid reasons for these concessions to alleged criminals, is current legislation in accord with those reasons? It is the purpose of this Note to examine the bases for enactment of statutes of limitations in criminal law, and to indicate certain problems and inconsistencies arising from the current status of these statutes in the United States.

The doctrine that no lapse of time bars the King (nullum tempus occurrit regi) ${ }^{3}$ has prevailed in England to the extent that there are relatively few statutes imposing time limitations on criminal prosecutions in English law. This doctrine has won little, if any, acceptance in other

1. Davenport v. State, 20 Okla. Crim. 253, 270, 202 Pac. 18, 24 (1921); Commonwealth v. Foster, $111 \mathrm{~Pa}$. Super. 451, 456, 170 Atl. 691, 692 (1934). Some authorities refer to the statutes as acts of "amnesty." 1 WuArToN, CrnMrnat PROCEDURE 415 (10th ed., Kerr, 1918); Matter of Doyle, 257 N.Y. 244, 256, 177 N.E. 489, 493 (1931). See also People y. Ross, 325 I11. 417, 420, 156 N.E. 303, 304 (1927): "Statutes of limitations in criminal cases differ from such statutes in civil cases, in that in the latter, they are statutes of repose while in the former they create a bar to prosecution."

2. 1 Wharton, op. cit. supra note 1, at 414; Clark, Crminar Procedure 149 (2d ed., Mikell, 1918); Arcebold, Criminal Pleading, Evidence \& Practice in CrIMINAL CAses 53 (31st ed., Butler and Garsia, 1943); see 2 STEPHEN, History of the CrIminal Law of ENGLAND 1, 2 (1883) for examples of old English cases in which prosecution was begun many years after the commission of the crime.

3. Archbold, op. cit. supra note 2, at 53; Kenney, Outlines of Crominal Law $\S 639$ (Turner ed. 1952).

4. The major crimes that are subject to a limitation in England are:

a. Treason-3 years generally. Treason Act, 1695,7 WILL. 3, c. 3, § 5; see 7 ANN., c. 21 (1708).

b. Carnally knowning a female $13-16$ years old-1 year. Criminal . Law Amendment Acts, 1885, 48 \& 49 Vict., c. 69, \$5; Criminal Law Amendment Acts, 1885 to 1925,18 \& 19 GEo. 5, c. $42, \S 41$.

c. Offenses punishable under Summary Jurisdiction Act-6 months. Summary Jurisdiction Act, 1848, 11 \& 12 VICT., c. 43, \$11.

d. Income Tax Act Violations-6 years generally. Income Tax Act, 1918, $8 \& 9$ GEO. 5, c. $40, \S \$ 221(3),(4)$.

e. Summary proceedings for perjury-1 year. Criminal Justice Act, 1925, $15 \& 16$ GEO. 5, c. $86, \S 28(3)$. 
countries. The civil law jurisdictions derive their criminal statutes of limitations from Roman Law which set a twenty year period after which liability for a crime was extinguished. ${ }^{5}$ The modern statutes of the civil law countries are similar to those now prevailing in the United States in that they generally provide the longest period of limitation for the most serious offense. ${ }^{6}$

The English policy of limited use of statutes of limitations has never been widely followed in the United States where criminal statutes of limitations made their appearance in the colonies as early as $1652 .{ }^{7}$ Such statutes were adopted for most crimes in the federal system in $1790^{8}$ and have per-

For other crimes see 9 HaLSBURY, Laws of ENGLAND 82, n.p. (2d ed. 1933). Formerly all actions on penal statutes where a forfeiture limited to the king was involved were subject to a statute of limitations. 31 ELIz., c. $5, \S 5$ (1589). This section was repealed by the Limitations Act of 1939, 2 \& 3 GEO. 6, c. 21, § 34 (1939). It should also be noted that this statute did not apply to common law crimes, being limited by its terms to actions on penal statutes. See generally, EspINASSE, LAw of Actions on Penal Statutes 71 et seq. (1st Am. ed. 1822).

Apparently no authoritative discussions exist as to why the use of criminal statutes of limitations is so restricted in England. It may be that the English have never felt any need for such statutes, or believe that certain characteristics of their criminal law procedure eliminate any need which might exist elsewhere. For example, English prosecutors are not employed solely as prosecutors and political careers are rarely dependent upon their success; as a result there may be a more careful weeding out of evidence in England. See generally, Howard, Crininal JUSTICE IN ENGLAND (1931).

5. Murray, The Prescription of Crime, 50 Scor. L. Rev. 259 (1934).

6. E.g., In the French Code the period of limitation for prosecution of different crimes depends upon a distinction similar to the American felony-misdemeanor classification, adding as a third group "contravention de police," or petty misdemeanors. There is an additional limitation on commencement of punishment, which begins to run from the day on which a final, non-appealable sentence is imposed; if punishment is not begun during this period, the offender's liability is extinguished. CODE D'INSTRUCTION CRIMINElle, Art. 634-643 (1808). In Italy the period required to bar prosecution is equal to the maximum prison sentence for the crime. However, the Italian Code provides more differentiation than is found in the United States, within the felony-misdemeanor classifications. See text at note 30 infra. Penal Code of the Kingdom of Italy, Art. 157-161 (1930). See also German PENAI CODE of 1871, as amended 1950, \$ 67; Code PENAL Sursse Art. 70-72 (1951). See the Criminal Code of the R.S.F.S.R., Part 111, $\$ 8$ (1937), as quoted in Dession, Criminal Law, Administration and Public Order 618 (1948); "In the event of a concrete act, which at the time it was committed was a crime . . . but by the time it was investigated or examined in court lost its socially dangerous character owing to a change in the criminal law or merely a change in the social-political conditions, or in the event the person who committed it cannot in the view of the court be any longer regarded as socially dangerous at that moment, the act shall not entail any measures of social defense against the person who committed it."

7. Whimarore, Colonial Laws of Massachusetts 163 (1889) (one year general limitation on crimes). See also Charter and Laws of the Province of PenNsylVANIA 1682-1700 173-4 (George, Neod, and McComant, 1879) (1684 statute prohibiting offenses against the Governor provided a six month limitation).

The far more extensive use of statutory limitations here than in England may have resulted from the fact that early in the development of American law there was a contest between the civil and common law for acceptance in the colonies. Howe, Readings in American IEgal History 19 et seq. (1949) ; Radin, ANgloAMrerican Legal History \&79 (1936). Probably in this area the civil law was accepted. Cf., Haskins, $A$ Problem of the Reception of the Common Law in the Colonial Period, 97 U. of PA. L. Rev. 842 (1949).

8. 1 Laws of the United States $113, \S 32$ (1789-91). 
sisted there ever since. ${ }^{9}$ Today, limitations are applied to most crimes by all but a few states, ${ }^{10}$ although the most serious crimes are frequently excepted. ${ }^{11}$

\section{PURPoses}

Criminal statutes of limitations ostensibly serve several purposes, all of which relate to the efficacy of criminal law administration. Since relevant legislative history is meagre, ${ }^{12}$ it should be noted that although the following purposes may be achieved by the statutes, such purposes did not necessarily motivate legislative enactment.

The most important reason for statutes of limitations is to protect the accused from the burden of defending himself against charges of longcompleted misconduct. ${ }^{13}$ As time passes, witnesses upon whom the defendant may need to rely die or move away; events are forgotten and records lost, particularly if the events seemed unimportant at the time of occurrence.

"Statutes of limitation are founded upon the liberal theory that prosecutions should not be allowed to ferment endlessly in the files of the government to explode only after witnesses and proofs necessary to the protection of the accused have by sheer lapse of time passed beyond availability." 16

Even where the defendant is guilty, circumstances which, at the time of commission, tend to mitigate his sentence, such as an adverse economic situation, fade into unimportance. While some of these factors are similarly detrimental to a delayed prosecution, it must be remembered that it is the prosecutor who exercises the option to proceed to trial.

Closely related to the protection of the defense as a purpose of limitations statutes is the desire to insure that criminal prosecution will be based on evidence that is reasonably fresh and therefore more trustworthy than evidence with a probative value which has grown weaker as man's ability to remember has become impaired. ${ }^{15}$

“. . . the very existence of the statute is a recognition by the legislature of the fact that time gradually wears out proofs of innocence

9. 18 U.S.C. \&3281 et seq. (1946).

10. See text following note 29 infra; South Carolina and Wyoming have no statutes of limitations. The following states have no limitation for felonies: Kentucky, Maryland, North Carolina, Ohio, Virginia, and West Virginia.

11. See text at and following note 33 infra.

12. E.g., 1951 U.S. CODE CONG. SERv. 1547; see also note 104 infra.

13. See Chafee, Thirty-five Years with Freedom of Speech 28 (1952). The importance of this factor received recognition early in English history. See 7 WIIL. 3, c. 3 (1695) ; 32 HeN. 8, c. 9 (1540).

14. United States v. Eliopoulos, 45 F. Supp. 777, 781 (D.N.J. 1942).

15. See text following note 44 infra. 
and a notification that a fixed and positive period established by it destroys all proofs of guilt." 16

It should be noted, however, that a statute of limitations is no assurance as to time of trial, since the finding of an indictment tolls the running of the statute but does not determine when trial will be held. ${ }^{17}$ It is at this point that the constitutional right to a speedy trial, ${ }^{18}$ often augmented by specific statutes, ${ }^{19}$ supplements the aim of the limitation. ${ }^{20}$

It has been suggested that statutes of limitations also aid the state in checking upon its officials by requiring vigilance on their part in discovering law-violators and bringing them to justice as speedily as possible. ${ }^{21}$ If limitations do bring to bear upon police and prosecutors more pressures than are caused by a citizenry aroused by recent crimes, it may be argued that these pressures are ineffective since present prosecutors are already overburdened with restrictions on personnel and finances. However, this problem should be remedied by improving prosecution facilities rather than by withholding the limitation.

The state should be most interested in punishing recent crimes, and the statutes tend, depending on the length of the period, to insure that this aim will be achieved..$^{22}$ It should be remembered that an individual who has committed criminal acts in the past and is still continuing to do so is committing recent crimes for which the statutes are no bar to prosecution.

16. People v. Ross, 325 Ill. 417, 421, 156 N.E. 303, 304 (1927). See also Hogoboom v. State, 120 Neb. 525, 527, 234 N.W. 422, 423 (1931); People ex rel. Reibman v. Warden of the County Jail at Salem, N. Y., 242 App. Div. 282, 284, 275 N.Y. Supp. 59, 62 (3d Dep't 1934).

17. See text at note 94 infra.

18. See e.g., U.S. Const. Amend. VI; Pa. Const. Art. I, §9; N.J. Const. Art. 1, §8; OnIo Const. Art. I, §10.

19. E.g., PA. Stat. ANs. tit. 19, §781 (Purdon 1930) (trial must be within two terms of court after indictment); GA. CODE ANN. \$27-1901 (1935); LA. Rev. STAT. ANN. \& $15: 318$ et seq. (West 1951).

20. In United States v. McWilliams, 69 F. Supp. 812, 815 (D.D.C. 1946), the court said: "As in all long delayed cases, the witnesses now are scattered; some are not accessible, more particularly to the defendants. . . the memories of witnesses as to events occuring many years ago are not clear. It is for those reasons among others that the Constitution of the United States has imposed [a] Statute of Limitations to prevent long delayed prosecutions. I do not see how these defendants now can possibly obtain fair trials." Aff'd and quoted in United States v. McWilliams 163 F.2d 695, 696 (D.C. Cir. 1947). See also United States v. Cadau, 197 U.S. 475 (1905); Ex parte Altman, 34 F. Supp. 106 (S.D. Cal. 1940).

Note that the constitutional right to a speedy trial is considered a personal one which may be waived by defendant's failure to demand prompt action. Collins v. United States, 157 F.2d 409 (9th Cir. 1946).

The right to a speedy trial after indictment was recognized at an early date in England. See Habeas Corpus Act, 1679, 31 CAR. 2, c. 2, \$7.

21. 1 Wharton, Criminal Procedure $\$ 367$ (10th ed., Kerr, 1918). One author has suggested that the deterrent effect of punishment is directly related to the speed with which criminals are brought to trial; the less time the criminal has to enjoy the fruits of his crime, the less desirable will criminal conduct appear to the potential criminal. See Howard, Criminar Justice in England 128, n.44 (1931).

22. Beccaria, Crmmes and Punishments 74 (2d Am. ed. 1819) ; Stallybrass, A Comparison of Criminal Laze in England in 4 ENGLISH Studies in Crminar SCIENCE 390, 443 (1945). 
On the other hand, those persons who have committed crimes in the distant past and have not repeated their errors are apparently self-rehabilitated and as a result seem to offer little cause for fear as to their future conduct. The pursuit of only more recent criminals is consistent with that aim of criminal law which seeks to rehabilitate wrongdoers and serves to free the citizen from vexatious fear of prosecution for old crimes. ${ }^{23}$ The criminal who has avoided prosecution for several years and who seeks to rehabilitate himself would be encouraged in this objective by the assurance that whatever progress he makes will not be shattered by enforcement of some long dormant claim of the state to his freedom. ${ }^{24}$

This security afforded by the statutes is only security from prosecution for crimes. There remains the possibility of public degradation by the disclosure of old crimes and the association of individuals with those crimes. The statutes, of course, do not prevent this sort of activity but as a matter of practice law enforcement officials rarely turn to the investigation and disclosure of crimes which cannot be the basis of convictions.

Although commentators have apparently offered no reasons for opposing statutes of limitations in the criminal law, there is the possibility that the statites may to a certain extent encourage criminal activity by diminishing the certainty of punishment. There may be a particular danger that where a first offender's prosecution is barred by a statute, he may be encouraged to return to criminal activity. With the habitual criminal upon whom prior legal sanctions have apparently had little effect, perhaps the criminal law is best served by his removal from society; to the extent that this is true, and assuming that there is no doubt of guilt, the statute of limitations is not desirable. Obviously, the statute also prevents realization of the state's desire for retribution.

One possible alternative to limitation statutes would be to grant discretion to either the court or the prosecutor to prohibit or discontinue prosecution if the interests of justice so dictate. Substantial discretion exists today in the prosecutor through his ability to refrain from prosecuting ${ }^{25}$ or to enter a nolle prosequi. ${ }^{26}$ However, the exercise of this discretion may be colored by political expediency and the desire to obtain as many convictions as possible. On the other hand, it may be argued that the desire to prosecute only cases with a reasonable chance for success

23. See Thayer, Schoch, and Ireland, The Effect of a State of War Upon Statutes of Limitation or Prescription, 17 Tulane I. REv. 416 (1943).

24. A much publicized example of the value of an opportunity for self-rehabilitation was the case of one Frank Raboski. After escaping from jail in California, Raboski went to Illinois and established himself as an outstanding citizen. When after many years he was finally confronted with the charges against him, the local citizenry campaigned for clemency because of his value to the community. See the description of the case in Time, May 11, 1953, p. 24, col. 3 .

25. As to criminal liability for improper exercise of this discretion, see State v. Winne, 12 N.J. 152, 96 A.2d 63 (1953), 102 U. of PA. L. REv. 547 (1954).

26. See e.g., Ohto Gen. Codr Ann. $\$ 13437.32$ (Page 1938) ; N.C. Gen. Stat. $\$ 15-175$ (1953); GA. CoDE ANN. tit. 27, \$1801 (1953). At common law the prosecutor also had this power Clark, CrTminal Procedures 154 (Mikell ed. 1918). 
would lead a prosecutor to proceed only when the evidence is not stale, thus eliminating one need for a statute of limitations; this theory assumes that juries reject stale evidence. Absent statutory authorization, the court has no power to direct the entry of a nolle prosequi. ${ }^{27}$ Statutory authorization to dismiss the action apparently exists only in states having statutes of limitations, ${ }^{28}$ but perhaps they could, if utilized in olace of statutorv limitations, produce the desired ends.

\section{The Current Statutes}

Existing statutes are of three general types: (a) some provide the same limitation period for all crimes $;{ }^{29}$ most make distinction's (b) in the length of the period on the basis of the classifications of felonies and misdemeanors, ${ }^{30}$ or (c) of crimes punishable by death, imprisonndent in the state penitentiary or in the county jail (which distinction is often synonymous with that between felonies and misdemeanors). ${ }^{31}$ In other words, where there are distinctions in the length of the period, their usual basis is the relative seriousness of the crime involved. As the chart in the appendix ${ }^{32}$ indicates, the most frequent period for felonies is three years, although a number of jurisdictions put no bar on them. Murder is subject to no limitation in all but one jurisdiction; ${ }^{33}$ arson, rape and forgery are free from limitation in about one-third of the states, and are subject to a three year limitation in several others. For robbery, kidnapping, embezzlement, bribery, perjury, and conspiracy about one-third of the states provide a three year limit, with some states providing no limit on the first three of these offenses, and only a few states denying any bar on the last three crimes.

Misdemeanors are generally treated as a group. The longest limitation period for misdemeanors is six years, found in four states; two states have no bar. Eighteen states provide a one year limit and fourteen, a two

27. State v. Anderson, 119 Tex. 110, 26 S.W.2d 174 (1930); See Note, 69 A.L.R. N.S. 240 (1930). But see, Williams v. State, 97 Ga. 398, 23 S.E. 822 (1896) (court ordered a nolle prosequi, one of the factors entering into the decision being the time lapse involved). However, in some circumstances the sentencing discretion of the judge is relevant to the problem. See text at note 50 infra.

28. Ore. Compr. Laws Ann. \$26-2005 (1940); Cax. Penal Code $\$ 1385$ (Supp. 1953). See State v. Keep, 85 Ore. 265, 166 Pac. 936 (1917); Jones v. Busby, 37 Okla. Cr. 68, 256 Pac. 758 (1927).

29. E.g., Iowa CODE ANN. c. 752, \$\$1-5 (1950); Kan. Genv. Stat. AnN. c. 62 , $\$ \$ 501-5$ (Corrick 1949). See note 10 supra to the effect that South Carolina and Wyoming have no statute and that six other states have no limit on felonies.

30. E.g., ARK. Stat. ANN. \$43-601, 43-602 (1947) (provides a three year limitation for felonies and one year for all offenses less than felonies); ALA. CODE ANN. tit. 15, $\$ \S 219-226$ (1940).

31. E.g. Conn. Rev. Gen. Stat. §8871 (1949); Mp. Ann. Code Gen. Laws Art. 57, \$\$11-12 (Flack 1951).

32. See chart, Appendix. Because some states have more than one limitation for a particular crime, the total numbers used in the text will often exceed fortyeight.

33. New Mexico has a ten year statute of limitations on murder. See chart, Appendix. 
year limit. Consistent with the policy of relating the length of the period to the gravity of the crime, prosecution for conduct which is illegal but lacking in moral turpitude (e.g., traffic violations) must usually be started within a period shorter than that for misdemeanors generally. ${ }^{34}$

The Federal Code provides a three year limitation on crimes ${ }^{35}$ with the following exceptions: (a) no limitation on capital offenses; ${ }^{36}$ (b) five year limitation on violations of the customs and slave trade laws; ${ }^{37}$ (c) one year limitation on criminal contempt charges ${ }^{38}$ (d) ten year limitation on violations of the naturalization laws. ${ }^{39}$ The new Code of Military Justice similarly applies the seriousness-of-the-crime criterion. ${ }^{40}$ The most serious crimes from the military standpoint are wartime desertion, wartime absence without leave, aiding the enemy, mutiny and murder. There are no limitations on these crimes, but the remaining crimes are given either a two or three year period depending upon their correspondence to the civilian law's classification of misdemeanors and felonies.

\section{Evaluation and Suggested Criteria}

In light of the rationale of statutes of limitations, there is little validity to the policy of relating the statutory period directly to the seriousness of the crime. Where a crime is especially serious and the punishment is correspondingly great it would seem particularly important to protect the defendant's right to garner reliable information for a defense and to prevent the use of stale evidence against him. It may be argued that in the most serious crimes with the most severe penalties, the stale evidence problem is reduced because a jury will scrutinize the evidence most carefully, but as the seriousness of the crime is increased so too is the likelihood of the jury's being swayed by emotion rather than logic. Where the security of a self-rehabilitated citizen is at stake, the more enormous the unpunished crime, the more the citizen has to fear from a delayed discovery and prosecution. In view of the factors weighing against a severity-of-crime approach to limitations on prosecutions, one is left with the conclusion that the chief motivation for such an approach is the desire for retribution; the more serious the crime, the more likely is it that this desire will outweigh the aims of limitation statutes.

Even assuming that statutes of limitations should be directly related to the seriousness of the crime involved, adoption of the existing felonymisdemeanor categories does not satisfactorily delineate the worse from the

34. E.g., PA. Stat. ANn. tit. 75, $\$ 731$ (Purdon 1953) (15 day statute of limitations for traffic violations).

35. 18 U.S.C. $\$ 3282$ (Supp. 1952).

36. Id. at $\$ 3281$.

37. Id. at $\$ 3283$.

38. Id. at $\$ 3285$.

39. Id. at $\$ 3291$.

40. Unif. Code of Military Justice Art. 43, 64 Stat. 121 (1950), 50 U.S.C. $\S 618$ (Supp. 1951). 
lesser crimes in all instances. The difficulties inherent in setting up any felony-misdemeanor classification have resulted in some distinctions which are at best dubious, and which are anomalous when carried over into statutes of limitations. For example, in Indiana if a public officer is bribed to procure a state contract, where the bribe was over two hundred dollars, the crime is a felony subject to a five year limitation, but for a lesser offer it is a misdemeanor subject to a two year limitation. ${ }^{41}$ Maryland bases its limitation periods on place of confinement for conviction of a particular crime ; ${ }^{42}$ under this rule an insurance agent who embezzles funds is subject to imprisonment in the state penitentiary and therefore to no statute of limitations, while an embezzlement by a transporter of goods, punishable by confinement in jail, is subject to a one year limitation. ${ }^{43}$

Instead of strict adherence to the felony-misdemeanor dichotomy in setting limitations on prosecution, there should be an attempt to weigh all factors which may affect the achievement of the aims of limitations statutes. Whether or not seriousness of the crime continues to be a factor because of the desire for retribution, other considerations should be taken into account. Legislators, in determining a particular limitation for a particular crime, should base the statutory period for the crime primarily upon the length of time during which the facts constituting the elements of the crime can be accurately ascertained, bearing in mind the time needed to discover and investigate the crime as promptly as possible.

\section{Reliability of Evidence}

Authorities on the law of evidence ${ }^{44}$ and psychologists recognize that there is a relation between the passage of time and the extent ${ }^{45}$ and accuracy ${ }^{46}$ of memory. Since the rate of forgetting depends upon variants such as the degree of learning, ${ }^{47}$ it is impossible to say that the passage of any particular length of time renders evidence unreliable. Nevertheless, the continuous nature of oblivescence serves to justify the application of statutory limitations on prosecution. On the other hand, there are some crimes in which memory is not so important a factor as in the usual case, because

41. Ind. Anv. Stat. $\$ \$ 9-304,10-603$ (Burns 1942).

42. Mo. Ans. Code Gen. Laws Art. 57, §11 (Flack 1951). See text at note 31 supra.

43. Md. Ans. Code Gen. Laws Art. 27, \$§ 156, 158 (Flack 1951).

44. See 3 Wigmore, Evidence \$745 (3d ed. 1940) (memoranda not made shortly after a transaction are inadmissible in court); Hutchins and Slesinger, Some Observations on the Law of Evidence-Memory, 41 HARV. L. REv. 860 (1928).

45. Ebbinghaus, Memory (Ruger's transl. 1913) ; Strong, The Effect of TimeInterval Upon Recognition Memory, 20 PsYCE. REv. 339 (1913). See generally, Arnold, Psychology Applied to Legal Evidence 167 (2d ed. 1913). The dates of the psychological studies indicate the need for modern research in the area. Up to date memory data could be a valuable aid in adjusting limitations statutes to the reliability of evidence.

46. Dallenbach, The Relation of Memory Error to Time Interval, 20 Psych. REv. 323 (1913).

47. Munn, Psychology 211 (1951). See also Husband, General Psychology 444 (1941). 
the crimes are evidenced by written matter. These crimes might include bank embezzlements, tax frauds, or prosecutions under the Fair Labor Standards Act. ${ }^{48}$ In setting limitations for such crimes the fact that the use of stale evidence by the prosecution is not an acute problem should be taken into account. However, other dangers of delayed prosecution must be considered, such as the difficulty of making a defense which may not be based on written evidence.

Subsidiary to the factor of guaranteeing the reliability of evidence is the problem of the self-rehabilitated individual. Since society may have more to lose than to gain in prosecuting a criminal who is unlikely to commit another crime, it is desirable to bar prosecution where there is a strong probability that self-rehabilitation has taken place. If it could be ascertained that abstinence from crime for a given length of time is a reliable indication of rehabilitation, this fact might be taken into consideration in enacting statutes of limitations. However, there have been no scientific studies of "self-rehabilitation" 49 and it is doubtful whether any formula could ever be devised to gauge the length of time within which it is probable that a person is rehabilitated. The importance of this consideration is reduced by the fact that a statutory period short enough to insure the use of reliable evidence would, in most cases, adequately safeguard the self-rehabilitated individual. In the case of the occasional criminal who has "gone straight" even before the expiration of such a statutory period, the discretionary powers of the prosecutor and the sentencing judge should be utilized to save the accused from prison..$^{50}$

Although the heart of an intelligently formulated statute of limitations must be the calculation of time periods based on the exclusion of stale evidence, no limitation can be set without regard to the length of time reasonably necessary to discover and investigate crimes. It is obvious that the shorter the amount of time from the commission of a crime to prosecution, the more reliable will be the evidence; it is also obvious that too short a period of time may preclude discovery and effective investigation.

\section{Time Necessary for Discovery and Investigation}

In determining the time ordinarily requisite for investigation, factors such as the difficulty of identifying suspects should be considered. For

48. The written evidence in a bank embezzlement prosecution would probably include cancelled checks, drafts, bank books and records. Similarly, in a case involving tax frauds, the evidence would center around accountant's records, cash receipts, and vouchers. Where the Fair Labor Standards Act, 52 STAr. 1068 (1938), 29 U.S.C. \$215 (1946), as amended, 63 STAT. 919 (1949), 29 U.S.C. $\$ 215$ (Supp. 1952), is involved, written evidence such as records of employment hours and wages, payroll checks and receipts is important.

49. However, there have been some studies in the related area of recidivism. For a review of these see Monachesi, American Studies in the Prediction of Recidivism, 41 J. CrTar. L. \& CrIMINologY 268 (1951).

50. On the scope and abuse of the judge's sentencing discretion, see Note, 101 U. of PA. L. Rev. 257 (1952). As to the prosecutor's discretion, see text at notes 25 and 26 sipra. The powers of the Governor and the Board of Pardons are also relevant to rehabilitation, but these come into play after the criminal has been sent to prison. 
example, crimes in which the victim is confronted by the criminal, such as attempted bribery, extortion or robbery, should require shorter periods of investigation than burglary or arson. ${ }^{51}$ Records of effective law enforcement agencies could provide information about reasonable investigative periods.

\section{Concealed Crimes}

Another important factor which should be considered in establishing the length of time allowable for prosecution is whether the nature of a particular crime (as distinguished from the efforts of the criminal) makes detection especially difficult. Although some statutes provide exceptions which toll their running as a result of the concealed nature of the crime or concealment of the commission of the crime by the offender, ${ }^{52}$ generally the matter has been given little attention. Certain crimes such as embezzlement and conspiracy are inherently concealed ones and would therefore seem to warrant special attention.

Embezzlement:-As with most other crimes the states base the period of limitation for embezzlement on the felony-misdemeanor dichotomy. The determination of whether embezzlement is a felony or misdemeanor usually turns on the person doing the embezzling or the amount that is taken. In the case of public officials in the course of their official duties the offense is generally a felony without regard to the amount taken. ${ }^{53}$ For such persons statutory provisions sometimes exist which delay commencement of the period either until the crime is or reasonably should be discovered or until the official leaves office, at which point discovery should be made. ${ }^{54}$ When the statute does not so delay commencement of the statutory period, the case law often produces the same result. For example, under a statute making it criminal to convert public money entrusted to the custody of a specified public officer, the court held that the statute began to run not from the time of the conversion, but from the time of a demand for the funds by the person authorized to make such a demand. ${ }^{\text {.5 }}$

51. See McGuinness v. United States, 77 A.2d 22 (D.C. 1950) in which defendant was charged with passing bad checks to the Government. The court held that the Wartime Suspension Act, 18 U.S.C. \$3287 (Supp. 1952) (see text at note 105 infra), was not intended to embrace the crime in question. Said the court, "[The Act's] purpose was to suspend the running of statutes of limitation applicable to offenses involving the defrauding of the Government. . . experience during the first World War showed that many offenses involving fraud on the Government were barred because they had not been discovered within time to proscute during the three-year period of limitation. It seems altogether clear that the passing of bad checks, which may and almost always would be discovered immediately, does not fall within such purpose." Id. at 25.

52. See e.g., GA. CODE ANN. §27-601(4) (1953) ; LA. Rev. Stat. §15:8 (1951); see also note 101 infra.

53. See e.g., Ind. Ann. Stat. \$\$ 9-304, 10-1702, 10-1703 (Burns 1942).

54. E.g., Fla. Stat. ANN. c. 932, §6 (1944); Ill. Stat. AnN. c. 38, §632(a) (Smith-Hurd Cum. Supp. 1952); PA. Stat. ANN. tit. 19, \$211 (Purdon Cum. Supp. 1952).

55. Commonwealth v. Shoener, 216 Pa. 71, 64 Atl. 890 (1906). Compare United States v. Irvine, 98 U.S. 450 (1878). 
Embezzlement by private persons is treated as a more or less serious crime-with consequent differences in the period of limitations-depending upon either the capacity in which the individual served or the amount taken. In specific situations statutes or cases sometimes delay commencement of the period until the individual has ceased to serve in the particular capacity. For example, in New York, a fiduciary's misappropriation does not start the statute running until the date on which his accounting is due.56 In Wisconsin, embezzlement by a bailee, if not discovered within the bailment period, is subject to prosecution for an additional year after discovery. ${ }^{57}$ Similar results have been obtained by decisions concerning conversion by a guardian or attorney. ${ }^{58}$

In some instances the problem of concealment is solved not by delaying the running of the statute but by providing a longer period for certain concealed crimes. For example, New Jersey imposes a two year limitation on crimes generally ${ }^{59}$ but a five year limit on embezzlement by a public officer or fiduciary. ${ }^{60}$ These lengthened provisions are less desirable than those which delay the running of the period since some embezzlements are or can be quickly discovered. In such situations, the statutes providing for unusually long periods are unnecessary, and do not accomplish the purposes which limitation statutes should serve.

Bribery:-In some states distinctions in limitations for bribery arise from the fact that bribery is classified sometimes. as a misdemeanor and sometimes as a felony, depending on the amount of the bribe ${ }^{61}$ or the person bribed. ${ }^{62}$ The statutes take no notice of the fact that bribery is to some extent a concealed crime and that therefore it would be desirable to have provisions delaying commencement of the period until discovery of the act or, in the case of a public official, until he leaves office. Lengthening the period for all briberies, or for briberies considered especially serious, is not the best solution to the problem of concealment, since, as with embezzlement, the crime may be discovered early while the disadvantages concomitant to delayed prosecutions remain.

Conspiracy:-Conspiracy is treated very much the same in most states; the most common limitation is three years, the next most common

56. N.Y. CRIM. CoDE $\S 142$.

57. WIS. STAT. $\$ 353.23(2)$ (1951) (one year after discovery with an outside limit of five years).

58. See Davis v. State, 28 Ala. App. 348, 185 So. 771 (1938) (guardian's embezzlement was not subject to the statute of limitations until after final settlement and demand for the fund; result is based on the theory that the crime was not the conversion but the failure to account). See also, Glenn v. State, 72 Okla. Crim. 165, 114 P.2d 192 (1941); State v. Thang, 188 Minn. 224, 246 N.W. 891 (1933); State v. Locke, 73 W. Va. 713, 81 S.E. 401 (1914).

59. N.J. Stat. Ann. tit. 2 A, c. $159, \S 2$ (1952).

60. Id. at $\S 3$.

61. E.g., Ind. ANN. Stat. §§10-603, 9-304 (Burns 1942).

62. In Ohio, bribery of a juror is a felony (OHIo GEN. Code ANN. \$12826 (Page 1938)) but bribery of a juror in a suit before a justice of the peace is a misdemeanor (Id. at $\$ 12828$ ). 
two years, and some states have no limitation at all. ${ }^{63}$ Where distinctions are drawn, the most prevalent one is between conspiracy to commit a felony and that to commit a misdemeanor, in each case adopting the limitation for the substantive crime. ${ }^{64}$ Similarly, where periods vary with the particular crime, the conspiracy period is the same as that for the offense which was the subject of the conspiracy. ${ }^{65}$

From the evidentiary point of view the analogy made by the statutes between the substantive crime and the conspiracy to commit it is justified by the fact that the proof of the conspiracy will be based mainly on proof of the commission of the crime by several persons, from which an agreement will be inferred. Since, for the most part, the same facts will be used to prove the conspiracy and the substantive crime, there is no reason for having a different period for the conspiracy itself. Although the crime of conspiracy is defined either as the illegal agreement, ${ }^{\text {b8 }}$ or the agreement plus an overt act, ${ }^{67}$ this distinction is not important for the purposes of present statutes of limitations since the crime is labelled a continuing one for which the limitation period begins as late as the last act.

\section{Continuing Crimes}

Important problems in considering the point at which a criminal limitation statute begins to operate are raised by the doctrine of the "continuing crime." Generally, a continuing crime is one which consists of a course of conduct enduring over an extended period of time, as contrasted with the instantaneous nature of most crimes. Crimes such as embezzlement, ${ }^{68}$ conspiracy, ${ }^{69}$ bigamy, $^{70}$ nuisance, ${ }^{71}$ failure to provide support ${ }^{72}$ or to register for the draft ${ }^{73}$ have been held to be continuing. The effect of the

63. See chart, Appendix.

64. E.g., Cal. Penal Code $\S 182$ (Supp. 1953) ; Colo. Stat. Ann. c. 48, $\S \S 446$, 177 (1935).

65. E.g., N.J. Stat. Ann. \$159-3 (1953) ; OkLa. Stat. ANn. tit. 22, § 152 (Supp. 1953) ; TENN. Code ANN. \$§ 11481 et seq., 11063 et seq. (Williams 1934); IND. ANN. Stat. \$\$9-301 et seq., 10-1101 et seq. (Burns 1942). (1940).

66. See Michaei \& Wechsler, Criminal LaW and Its Administration 636

67. 18 U.S.C. $\$ 37$ (Supp. 1952).

68. State v. Thang, 188 Minn. 224, 246 N.W. 891 (1933). But cf. State v. Marple, 13 N.J. Misc. 793, 181 Atl. 278 (Sup. Ct. 1935).

69. United States v. Graham, 102 F.2d 436 (2d Cir. 1939) ; State v. Ellenstein, 121 N.J.L. 304, 2 A.2d 454 (Sup. Ct. 1938).

70. Cox v. State, 117 Ala. 103, 23 So. 806 (1898); State v. Sloan, 35 Iowa 217, 7 N.W. 516 (1880). Contra: Pitts v. State, 147 Ga. 801, 95 S.E. 706 (1918). Of course the statutory phrasing is crucial in all cases. Compare People v. Brady, 257 App. Div. 1000, 13 N.Y.S.2d 789 (2d Dep't 1939), with Commonwealth v. Ross, 248 Mass. 15, 142 N.E. 791 (1924).

71. State v. Ireland, 126 N.J.L. 444, 20 A.2d 69 (Sup. Ct. 1941); State v. Dry Fork R.R., 50 W. Va. 235, 40 S.E. 447 (1901). Cf., Hull v. London County Council, [1901] 1 K.B. 580.

72. Richardson v. State, 30 Del. (7 Boyce) 534, 109 Atl. 124 (Ct. Gen. Sess. 1920); Towns v. State, 24 Ga. App. 265, 100 S.E. 575 (1919). (1947).

73. Fogel v. United States, 162 F.2d 54 (5th Cir.), cert. denied, 332 U.S. 791 
continuing crime doctrine on the law of criminal limitations is to cause the statute to run not from the initial act, which may in itself embody all of the elements of the crime, but from the occurrence of the most recent act. For example, when bigamy is defined as a continuing crime, the statute of limitations does not commence from the date of the bigamous marriage but can commence as late as acts of bigamous cohabitation occur. ${ }^{74}$ Similarly, failure to provide support for a spouse or child, since it is a "continuing crime," will not start the statute running until the last such failure occurs. $^{75}$

Theoretically, the "continuing crime" doctrine is valid in that it is most often applied to courses of conduct in which each individual act constitutes antisocial behavior. On the other hand, the effect of the doctrine may be a conflict with the purposes of the statute of limitations since evidence of acts which would ordinarily be barred by the statute are admissible to prove acts which are not so barred. For example, assume that a statute provides a three year limitation on prosecutions for a certain type of conspiracy. Assume further a set of circumstances constituting the conspiracy occurring in 1950 , and acts sufficient to cause the crime to be "continuing" occurring until 1954 at which time the statute begins to operate. Prosecution for the 1954 acts will undoubtedly result in introduction of evidence of the 1950 acts which, but for the "continuing" nature of the crime, would have been barred. As to these acts, the purpose of the statute has been circumvented.

As long as a definite pattern of antisocial behavior is present, however, the fact that the purpose of the limitation is overcome in some instances, does not make the "continuing crime" doctrine undesirable. The main problem is in determining what sort of crimes are "continuing" for purposes of the statutes of limitations; examination of several Supreme Court decisions may illustrate how that determination is made. In United States v. Kissel ${ }^{\mathbf{7}}$ the defendants were indicted for a conspiracy to restrain trade in violation of the Sherman Act. ${ }^{77}$ Defendants contended that the alleged conspiracy existed and was complete at the time the agreement to restrain trade was entered into, that such a conspiracy could not be continuing and that therefore prosecution was barred by the statute of limitations. The Court, per Mr. Justice Holmes, in holding that a conspiracy could be continuing up to the period of abandonment ${ }^{78}$ or success, stated:

"It is true that the unlawful agreement satisfies the definition of the crime, but it does not exhaust it. It also is true, of course, that the mere continuance of the result of a crime does not continue the crime.

74. See cases cited note 70 supra.

75. See cases cited note 72 supra.

76. 218 U.S. 601 (1910).

77. 15 U.S.C. $\$ \$ 1-7$ (1946).

78. See Hyde v. United States, 225 U.S. 347 (1912); Buhler v. United States, 33 F.2d 382 (9th Cir. 1929); Eldridge v. United States, 62 F.2d 449 (10th Cir. 1932); United States v. Ames, 39 F. Supp. 885 (S.D.N.Y. 1941). 
. . But when the plot contemplates bringing to pass a continuous result that will not continue without the continuous cooperation of the conspirators . . . and there is such continuous cooperation, it is a perversion of natural thought and of natural language to call such continuous cooperation a cinematographic series of distinct conspiracies, rather than to call it a single one." 79

In United States $v$. Irvine ${ }^{80}$ the question was whether the crime of withholding pension funds was a "continuing" one so as to remove the bar of the statute of limitations. In holding that the crime was complete upon a refusal to turn over the funds within a reasonable time after demand, the Court said:

"It is unreasonable to hold that twenty years after this [the original refusal upon demand] he can be indicted for wrongfully withholding the money, and be put to prove his innocence after his receipt is lost, and when perhaps the pensioner is dead. . . ." 81

In this case, after originally converting the funds, there was "continuance" only in the sense that the results of the crime remained after its commission; to extend the period of limitation under such circumistances would obviously reduce the statutes to an illusory bar.

That it is not always an easy matter to differentiate between a criminal act and its results for purposes of the statute of limitations is illustrated by the case of Pendergast $v$. United States. ${ }^{82}$ There the defendants, by fraud and deceit and through the misrepresentations of attorneys, induced the court to issue decrees effectuating a corrupt settlement of litigation. An information against defendants was drawn on the theory that the fraudulent scheme, although commenced beyond the three year period of the statute of limitations, ${ }^{83}$ continued thereafter. The prosecution contended that successful execution of the scheme required not only misrepresentations to the court, but also continuous cooperation in concealing the plan until the court, by virtue of its decree, had distributed certain impounded monies. The Supreme Court held the statute to be a bar on the ground that the prosecution was based on a section of the Judicial Code which created the power to punish contempts in cases of misbehavior in the presence of the court, $^{84}$ and therefore later acts could not make the crime a continuing one, although they affected court proceedings. The Court noted that the identical fraudulent scheme would be a continuing crime if prosecution were brought under a section of the Criminal Code dealing with corruptly obstructing the due administration of justice. ${ }^{85}$

79. United States v. Kissel, 218 U.S. 601,607 (1910).

80. 98 U.S. 450 (1878).

81. Id. at 452 .

82. 317 U.S. 412 (1943).

83. 19 STAT. 32 (1876), 18 U.S.C. \$582 (1940).

84. 36 SтAт. 1163 (1913), .28 U.S.C. 385 (1946).

85. 18 U.S.C. $\$ 1503$ (Supp. 1952). 
Mr. Justice Jackson, dissenting, thought that the action was not barred because:

“. . . The fraud had as its object not merely to get the Court order,

but to get the money from the Court's custody. The contempt and the fraud did not cease to operate so long as the money was being disbursed in reliance upon it, and by virtue of its concealment." ${ }^{86}$

In some cases the application of the continuing crime doctrine has led to seemingly unsatisfactory results from the standpoint of the purposes of statutes of limitations. For example, in State $v$. Ireland, ${ }^{87}$ an architect was convicted of creating a public nuisance when the structure which he had designed contrary to a building code collapsed thirteen years after its completion. Notwithstanding a two year limitation period, the court, by holding the crime a continuing one, was able to affirm a conviction for a thirteen year old crime. Even though the result in such a case may be justified if the principal evidence of the crime is the collapse of the building, the use of the "continuing crime" concept is at best questionable. It would seem better to draft a longer limitations period for construction crimes than to set dubious precedents by extensions of the continuing crime doctrine.

Another illustration of a debatable application of the doctrine for statute of limitations purposes is Fogel v. United States. ${ }^{88}$ An indictment was filed on January 22, 1947 charging defendant with having wilfully failed to register for the draft in 1942.89 Defendant was convicted despite his claim that the three year statute of limitations ${ }^{90}$ had run against the alleged crime. The court reasoned that the crime was a continuing one, because defendant had a duty to register on the official registration day and every day thereafter. One judge dissented on the grounds that the initial failure to register was a completed crime, and that even though subsequent failures to register were crimes in themselves, this did not affect the statutory bar to prosecution for acts occurring before the three year period: "The theory of the conviction is that by doing nothing he renewed his crime every day to the date of trial; which amounts to saying there is no statute of limitations for this offense." 91 An obvious difficulty with the rule of the Fogel case would arise where the defense was that the defendant did in fact register in 1942. Under such circumstances defendant would be forced, contrary to the policy of the limitation statute, to produce evi-

86. Pendergast v. United States, 317 U.S. 412, 422 (1940).

87. 126 N.J.L. 444, 20 A.2d 69 (Sup. Ct. 1941). But of. Hull v. London County Council, [1901] 1 K.B. 580.

88. 162 F.2d 54 (5th Cir.), cert. denied, 332 U.S. 791 (1947).

89. See Selective Training and Service Act, 55 STat. 844 (1941), 50 U.S.C. ApP. $\$ 302$ (1946).

90. 18 U.S.C. $\$ 3282$ (Supp. 1952).

91. Fogel v. United States, 162 F.2d 54, 56 (5th Cir.), cert. denied, 332 U.S. 791 (1947). 
dence on facts which occurred more than three years prior to the indictment.

That the problem of the continuing crime is a perplexing one is illustrated by the foregoing cases. Despite the doctrine's validity in many situations, it should be applied only on a limited scale; by applying the doctrine loosely, courts have a potentially powerful weapon for the avoidance of statutes of limitations.

\section{Tolling and Avoming the Statute}

The existence of a statutory limitation on a crime does not mean that it will be applied in every case in which that crime is alleged. A number of exceptions are written into the statutes, and in addition to these exceptions there are some situations in which the statutes are not an effective bar to prosecution. The most direct way of avoiding limitations would be by legislative amendment to extend the period. Such an amendment does not affect an individual for whom the statute has become a bar, on the theory that to allow such an effect would constitute a violation of the prohibition against ex post facto lawes. ${ }^{92}$ However, where the statute has not fully run, amendments which extend the period are permitted, ${ }^{93}$ a harsh result for the individual who is within a few days of the bar. The various methods of tolling and avoiding limitations merit discussion with a view to determining the validity of these exceptions in the light of the purposes of limitation statutes.

\section{Statutory Exceptions}

Practically every statute of limitations provides that the running of the statute is tolled when certain circumstances occur, such as when an indictment is found or when the defendant has fled the jurisdiction. In addition, there was a wartime suspension of federal limitations on the crime of defrauding the government.

Finding of an Indictment:-Generally, statutes of limitations are tolled upon the finding of an indictment; ${ }^{94}$ when the statute says only that the prosecution shall "commence" at a particular time it has been held that the statute is tolled by the filing of a complaint.95 This means that a statute of limitations would give little assurance that the trial will be held when the facts are fresh, except for the constitutional right to a speedy trial. ${ }^{98}$ The fact that the evidence needed to obtain an indictment is usually noted in the grand jury minutes does not compensate for tolling of the statute. Since the defendant's witnesses and evidence are not brought before the

92. Black, Statutes of Limitation and the Ex Post Facto Clauses, $26 \mathrm{Ky}$. L.J. 41 (1937).

93. Travis, Effect of Amendment Extending Period of Prosecution of Criminal Actions, 7 IND. L.J. 230 (1932).

94. Guise v. State, 198 Ark. 767, 131 S.W.2d 631 (1939) ; Brown v. Commonwealth, $255 \mathrm{Ky} .486,74$ S.W.2d 939 (1934).

95. State v. Gardner, 112 Conn. 121, 151 At1. 349 (1930).

96. See notes 18,19 and 20 supra. 
grand jury, the defendant is not present to cross-examine witnesses, and grand jury minutes are not readily available to a defendant, ${ }^{97}$ any evidence which is preserved by the grand jury proceedings tends only to harm the defendant.

When an indictment is found the statute ceases to run until such time as the indictment is quashed, dismissed, lost, mislaid, stolen or destroyed.98 The fact that the statute resumes operation after one of the above occurrences serves as an inducement to the prosecution to remedy correctible defects in its first indictment. This would not seem to impose great hardship upon the prosecution even where the indictment was lost, stolen, destroyed or quashed for a "technical" error (such as a misspelled name). If the prosecution had sufficient facts and evidence to obtain the initial indictment, the drawing of a new indictment or the correction of errors will take little time.

Fleeing the Jurisdiction:-Many statutes provide for a tolling of the statute when the defendant flees the jurisdiction. ${ }^{99}$ To the extent that most of the facts and evidence of the crime are within the knowledge and control of the defendant, his absence from the jurisdiction is a great impediment to police investigation. This is particularly true of a first offender whose modus operandi and possible associates are unknown to the police. In addition, questioning of suspects is one of the most widely used means of criminal investigation; such a procedure would undoubtedly be frustrated without the instant type of provision. This provision may be justified in that it removes an important cause for fleeing the jurisdiction, i.e., gaining the benefits of the statutory bar while at the same time receiving possible sanctuary from investigation. ${ }^{100}$

Closely related to the provisions concerning fleeing the jurisdiction are those provisions that toll the statute when the fact of the crime is concealed, ${ }^{101}$ or the offense or offender is unknown. ${ }^{102}$ Such concealment

97. United States v. Violon, 173 Fed. 501 (S.D.N.Y. 1909); See Dession, Criminat. Law, Administration and Public Order 933 (1948).

98. E.g., Irl. Ann. Stat. c. 38, §633 (Smith-Hurd 1935) ; Aza. Cone Ann. tit. 15, \$226 (1940). See also FIA. STAT. ANN. c. 24, \$932.05 (1944) (if the first indictment is before the bar, and is quashed after the statute runs, the prosecution has an added three months within which to bring the second indictment). 18 U.S.C. $\$ \S 3288,3289$ (Supp. 1952), provide that where an indictment is dismissed because defective or insufficient, the statute of limitations does not bar the bringing of a new indictment during the next succeeding regular term of court during which a grand jury is in session.

99. E.g., Dex. Rev. Code tit. 11, §2903 (1953); NeB. Rev. Stat. c. 29, §110 (1948); N.H. Rev. Laws c. $427, \S 13$ (1942); ORE. CoMp. Laws ANN. §26-203 (1940).

100. These considerations are mitigated to the extent that interstate cooperation exists in the investigation of crimes. See also, Uniform Criminal Extradition Act, 9 U.L.A. 173, §2 (1942).

101. Ind. Stat. Ann. \$9-305 (Burns 1942); Kan. Gen. Stat. AnN. c. 62, $\S 504$ (1935); Tenn. Code ANn. \$11488 (Michie 1942).

102. GA. Code ANN. tit. 27, $\S 601$ (1953). As to whose knowledge is required to start the statute, see Brown v. State, aff'd per curiam, 6 Ga. App. 329, 64 S.E. 1001 (1909); Cohen v. State, 2 Ga App. 689, 59 S.E. 4 (1907). But cf., State v. Watson, 145 Kan. 792, 67 P.2d 515 (1937). 
means more than mere "nondisclosure" and these provisions are strictly interpreted in order to protect the defendant. The criterion laid down by one court was:

"To constitute concealment it must appear that the statements or conduct of the accused was calculated and designed to prevent discovery of the crime with which he is charged; mere silence, inaction, or nondisclosure is not enough." 103

Such provisions, although desirable to avoid the frustration of police investigation, weaken the evidence by extending the period.

Wartime Suspension:-The disruption of government investigatory procedure during World War II led the Federal Government to consider suspension of the federal statute of limitations. However, such a drastic step was deemed unnecessary. ${ }^{104}$ Suspension was limited to the crime of defrauding the government which, because of its concealed nature, is particularly difficult to disclose. ${ }^{105}$

Considerable litigation developed concerning the nature of the crime of "defrauding the United States" as that term is used in the Code. In 1953 the Supreme Court in Bridges $v$. United States ${ }^{106}$ finally decided the issue by holding that the provision included only "pecuniary" or "property" frauds. The majority of the Court relied both on the rule of statutory construction that exceptions to a statute of limitations are to be strictly construed, ${ }^{107}$ and on the legislative history ${ }^{108}$ which indicated that Congress was considering pecuniary frauds. The dissent illustrated the unreasonableness of excluding other wartime frauds equally difficult to discover, stating:

"Certainly frauds impairing, obstructing or defeating selective service, alien property, administration of prices and wages and the allotment of scarce material, as well as the Immigration and Nationality Act, would hardly be omitted knowingly by Congress from a suspension of limitation for frauds against the Government. Yet many of these would fall under the Court's interpretation. . . . It was as hard, perhaps harder, to find and punish frauds against administration as those of a pecuniary or property nature. A general amnesty bill against war frauds would be fairer than to hold only those guilty of financial frauds. Both the purpose and the language of the Suspension Act

103. State v. Watson, supra note 102, at 794, 67 P.2d at 517.

104. Hearings before Subcommittee of the Committee on the Judiciary on H.R. 4916, 77th Cong., 1st Sess. 6 (1941).

105. 18 U.S.C. $\$ 3287$ (Supp. 1952).

106. 346 U.S. 209 (1953).

107. Id. at 216. See United States v. McElvain, 272 U.S. 633 (1926); United States v. Scharton, 285 U.S. 518 (1932).

108. H.R. REP. No. 365, 67th Cong., 1st Sess. 1 (1921) ; S. REP. No. 1544, 77th Cong., 2 d Sess. 1, 2 (1942); H.R. ReP. No. 2051, 77th Cong., 2d Sess. 1, 2 (1942); Hearings before Subcommittee No. 4 of the House Committee on the Judiciary on H.R. 4916, 77 th Cong., 1st Sess. 68 (1941). 
lead to the conclusion that frauds against administration are within its scope." 108

Since there were no additional resources available to aid governmental investigation during the war, suspending the statute of limitations was not merely a collateral solution as in the case of the usual overburdened prosecutor. ${ }^{110}$ The Federal Government was logically faced with only two alternatives: the suspension of the statute, or the possibility of allowing many violators to escape prosecution.

\section{Treatment of Juveniles}

A special problem exists as to whether criminal statutes of limitations apply to those within the jurisdiction of the juvenile courts. There is no case law on point and the statutes do not specifically deal with the problem. The argument against applying time limitations to juvenile proceedings is based on the fact that juvenile offenders receive statutory treatment differing from that designed for ordinary criminals. ${ }^{111}$ The juvenile court judge has much broader discretionary powers than the judge in an ordinary criminal case. The purpose of juvenile procedure is to treat and rehabilitate the minor without concern for retribution. It would, therefore, seem that if a judge determines that a minor having committed a past offense has since become a law abiding citizen, the minor would be dismissed. Since juvenile proceedings are generally not open to the public, the mere fact that the minor is brought in will not result in the community attitudes which usually accompany the criminal prosecution of the ordinary defendant. It is thus arguable that there is no need for a statute of limitations where juveniles are concerned. The same factors may have led to the statutory provisions which deny to a juvenile the right to such protections as jury trials and preliminary hearings. ${ }^{112}$

On the other hand, the mere fact that juvenile proceedings do not have all of the attributes of the ordinary criminal trial does not necessarily mean that the area should be free from statutes of limitations. The fact that the judge has broad discretion offers great opportunity for abuse; the fact that proceedings are behind closed doors eliminates the natural check on unfairness provided by public attention; problems of the reliability of evidence are still present. While application of a statute of limitations in these cases would provide a check on arbitrary action by the juvenile court, such

109. 346 U.S. 209, 230 (1953) (Court's footnotes omitted). In 1951 Congress enlarged the limitation for Naturalization Act violations from three years (which was a reduction from the prior five year limit of the 1948 revision) to ten years. 18 U.S.C. $\$ 3291$ (Supp. 1952).

110. See text following note 21 supra.

111. E.g., PA. STat. ANw. tit. 11, \$\$243 et seq. (Purdon 1939); N.Y. CHILDREN'S CouRT ACT \$14. For studies of juvenile court laws in general, see Mack, The Juvenile Court, 23 HaRv. L. Rev. 104 (1909); Consulich, JuveniLe CourT Laws of THE UNITEd States, (2d ed. 1939). See also, Van Waters, The Socialization of Juvenile Court Procedure, 13 J. CRnM. L. \& CRIMINology 61 (1922).

112. Ibid. 
a provision would not seem to impede the purpose of Juvenile Court Acts. ${ }^{113}$ Moreover, in situations where a statute of limitations would be relevant, it is probable that treatment of the minor is unwarranted.114

\section{Waiver}

In addition to express or implied exceptions to the statutes, the question arises as to whether a defendant may waive the protection of the bar by his conduct. The case law on this subject, though scanty, indicates that a waiver will result from a plea of guilty to an indictment which appears to be barred by the statute. ${ }^{115}$ The decisions concern themselves mainly with questions of the proper procedure by which the issue of the bar is raised and proved. ${ }^{116}$ Little consideration, if any, is given to the question of whether the public policy that gave rise to the statute should permit waiver under any circumstances. ${ }^{117}$ One answer to this question might be that once the facts are admitted, the statute is unnecessary for evidentiary purposes. However, a plea of guilty here, as well as generally, is only as efficacious as it is accurate and therefore the unreliability of evidence because of passage of time is an essential consideration despite such a plea.

\section{Perjury and the Limitation Statutes}

The now famous case of United States $v$. Hiss ${ }^{118}$ illustrates the problem of the use of an indictment for perjury as a means of allaying the consequences of statutes of limitations. In that case, defendant was indicted for perjury in falsely testifying to his part in alleged espionage activities, prosecution for which was barred by the statute of limitations. Without considering the merits of the factual issues presented, it is clear that the defendant was forced to rely for his defense to the perjury charge upon the same facts and evidence which would have constituted his defense to the barred espionage charge. Similarly, the prosecution was relying upon evidence which the statute of limitations on espionage was designed to exclude. It is important to note, however, that perjury convictions require

113. See the American Law Institute's proposed Youth Court Act which provides: "Every person charged with a violation of law and within the jurisdiction of the Youth Court is entitled to . . . all . . . rights, privileges and immunities which he would have under the laws of this state if he were an adult proceded against in a criminal court upon charge of a similar violation of law." A.L.I., Youth Court Act \$34 (Tent. Draft No. 1, 1940).

114. One judge in the Philadelphia Municipal Court who handles juvenile cases indicated that a child who appeared before him and whose only misconduct took place a number of years in excess of the statutory period would not be subjected to any treatment.

115. State v. Brinkley, 193 N.C. 747, 138 S.E. 138 (1927); Commonwealth ex rel. Patterson v. Ashe, $154 \mathrm{~Pa}$. Super. 397, 36 A.2d 249 (1943).

116. People v. Blake, 121 App. Div. 613, 106 N.Y. Supp. 319 (1st Dep't 1907); United States v. Cook, 17 Wall. 168, 179 (U.S. 1872).

117. But cf., 1 Ops. ATT'Y GEN. 383, 384 (1820).

118. 185 F.2d 822 (2d Cir. 1950), cert. denied, 340 U.S. 948 (1951). 
the testimony of two witnesses or one witness and corroborating evidence, thus diminishing the use of circumstantial evidence. ${ }^{119}$ To this extent the burden on the prosecution may be greater than in the proof of the substantive crime.

Since prosecutions for perjury are essential insofar as they seek to insure the giving of accurate and reliable testimony in proceedings of public importance, it might be argued that the fact that an occasional defendant is convicted of lying about a crime barred by the statute of limitations does not warrant concern. Whether or not such an argument has merit under conditions where perjury prosecutions are few and far between, the fact is that today there is an ominous use of perjury indictments against persons who have allegedly lied about acts barred from prosecution by the statutes of limitations. Consider the statement of Professor Zechariah Chafee:

"I am disturbed by the growing use of perjury prosecutions to bypass the Statute of Limitations. One of the main purposes of this statute is to protect innocent persons who might not be able to defend themselves against a charge of an antiquated crime, because of the difficulty of digging up recollections and documents about events a dozen years old, especially when they seemed of no importance at the time. Getting a man prosecuted for perjury if the grand jury happens to disagree with his memory of events long buried appears to be legally valid but it is nothing to be proud of." 120

To a great extent, the controversy over such use of perjury can be attributed to the growing importance of legislative investigations and the wide area within which they may operate. ${ }^{121}$ Where the scope of interrogation covers a long period of time prior to the investigation, the witness must recall events which the statute of limitations recognizes as being too old to warrant criminal prosecution. ${ }^{122}$ Legislative committees, of course, must be allowed wide access to facts so that they can perform legislative functions in the most informed manner possible. It would be untenable to suggest that the information available to legislative bodies be limited to

119. United States v. Remington, 191 F.2d 246 (2d Cir. 1951):

120. Chafee, Thirty-Five Years with Freedom of Speech 28-9 (1952).

121. "So that even as to ordinary subjects, the power of inquiry by the legislature is co-extensive with the power of legislation and is not limited to the scope or the content of contemplated legislation.... [T] he possibility that invalid as well as valid legislation might ensue from an inquiry does not limit the power of inquiry. . ." Barsky v. United States, 167 F.2d 241, 245 (D.C. Cir. 1948). See also Kilbourne v. Thompson, 103 U.S. 168, 190 (1880) (neither house of Congress possesses a "general power of making inquiry into private affairs of the citizen"); McGrain v. Daugherty, 273 U.S. 135 (1926); Landis, Constitutional Limitations on Congressional Power of Investigation, 40 HARv. L. Rev. 153 (1926).

122. For example, Owen Lattimore, when interrogated by the Senate Internal Security Subcommittee, was questioned as to his knowledge that one Asiaticus was a Communist in the late 1930's. His answer to this question, inter alia, was the basis of a perjury indictment. See United States v. Lattimore, 122 F. Supp. 507 (D.D.C. 1953); 102 U. OF PA. L. Rev. 251 (1953). 
any particular period of time; the purpose of a statute of limitations in protecting an individual from prosecution on the basis of ancient evidence does not call for a restriction of the facts upon which legislation may be based.

Therefore, where the purpose of the investigation is to seek a foundation for legislation, it is probable that the extent to which statutes of limitations are by-passed is outweighed by the need for honest testimony as guaranteed by the perjury sanction. On the other hand, if the investigation is aimed at particular individuals rather than legislative goals ${ }^{123}$ the balance would seem to shift to the protection of the individuals intended by the statutes of limitations. In the latter case the circumvention of the statutes appears to be a principal purpose of the investigation; in the former, circumvention occurs as a collateral incident to the investigatory purpose.

A practical method of resolving the conflict between perjury charges and the statutes of limitations is difficult to formulate. At least in the area of legislative investigations, the answer appears to be in the hope for selfrestraint on the part of the legislators and prosecutors; or perhaps in a reexamination of legislative controls limiting the powers and functions of the investigators.

\section{Concluston}

Statutes of limitations are, to some degree, in conflict with the deterrence and retribution aims of the criminal law. However, it seems clear that such statutes are essential in a system of criminal law which is designed to afford to individuals the utmost protection from unjust prosecution. This need has been recognized to the extent that most states have adopted statutory limitations for all but the most serious crimes; unfortunately, the existing statutes seem to have been drafted with little consideration of the aims which the limitations should achieve, that is, the assurance of a maximum degree of availability and reliability of evidence consonant with an adequate allowance of time for investigation and prosecution. Furthermore, the development of exceptions and devices for avoiding the statutes has curtailed the protection which such statutes should offer.

The most disturbing aspect of this area of the law is the apparent lack of consideration of the many problems raised by the present statutes, as evidenced by the paucity of authoritative discussion and investigation. A rational system of iimitations, designed to prevent convictions where pertinent evidence is unavailable or unreliable because of the passage of time, cannot be established until scientific analysis of the relationships of time to evidentiary needs, and the factors relevant to efficient investigation and disclosure of each type of criminal activity, is made available to the legislatures.

123. For discussions of committee technique see Countryman, UN-AMrerican Activttes in the State of Washington (1951); Ogden, The Dies Commitree (1945); Carr, The House Coximittee on Un-American Áctivities (1952). 


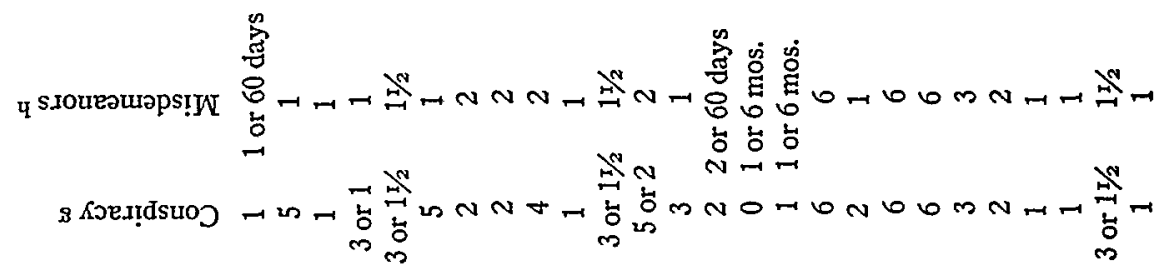

$$
\operatorname{singlad} m \text { m }
$$

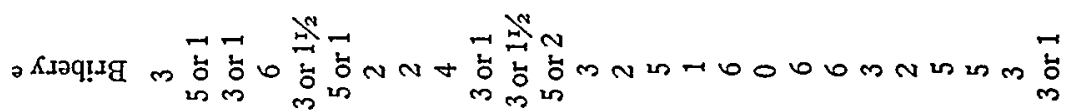

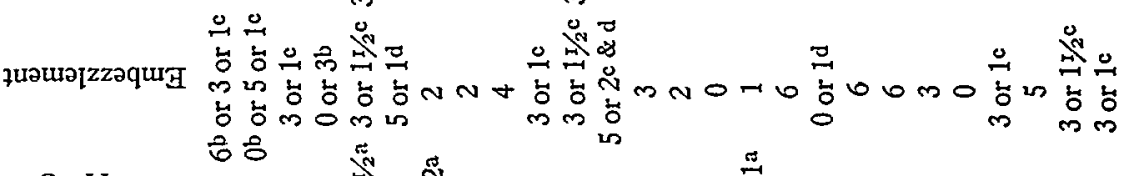

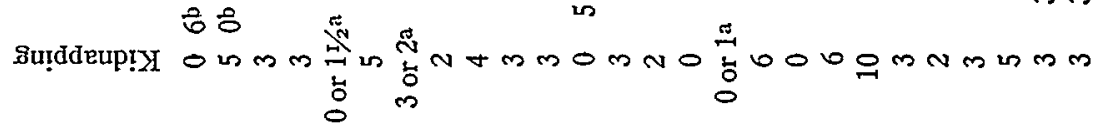

$$
\text { kraqqoy onmmmunn }
$$

KIJ8I0] onm in

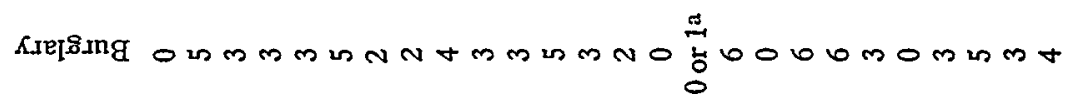

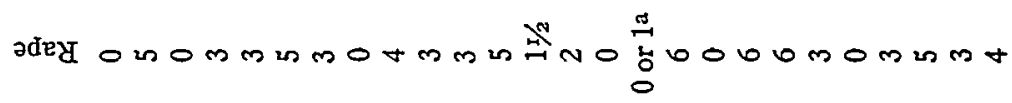
nosit onmmm nntmotom

(วอรภว $175 \mathrm{I})$

JapinfN 00000000000000000000000000

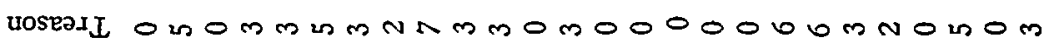

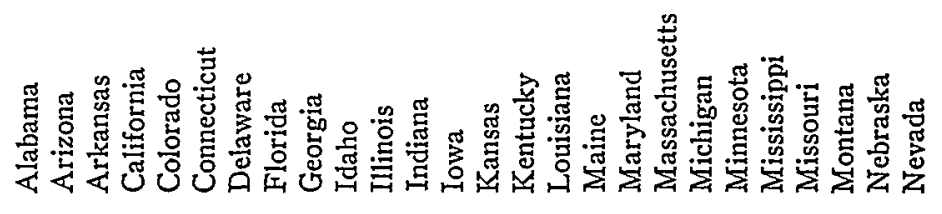




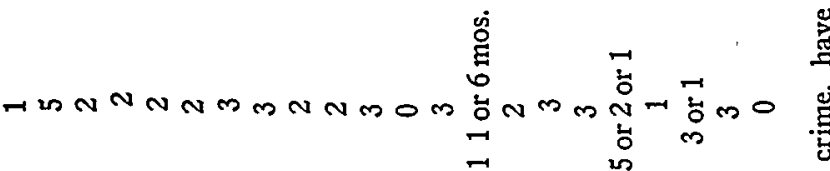

$\stackrel{2}{8}$

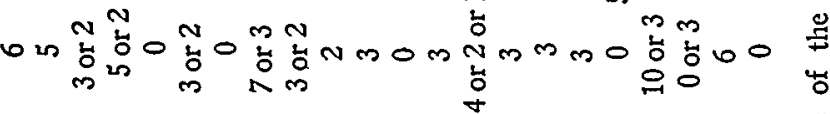

草

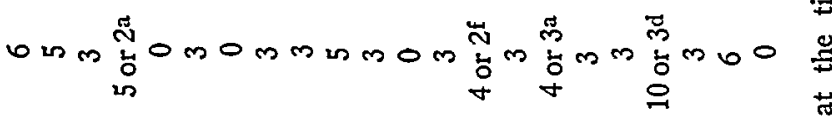

$+$

苞

$\cong$

$\ddot{\circ}$

.

药

.

.$\overline{0}$

要

(2)

言富焉

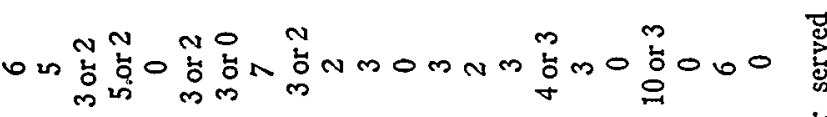

施

泀

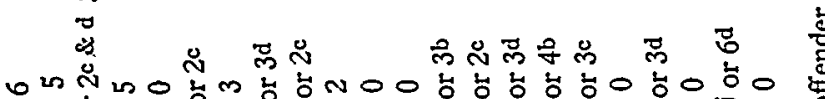

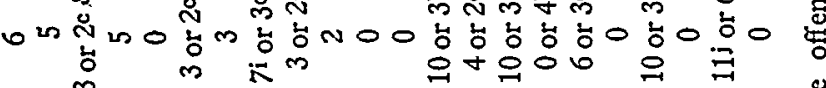

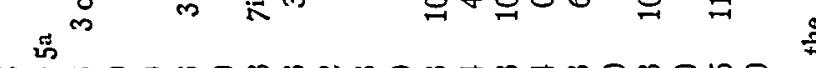
OL

OnminomommoOmtnt

OnMmOMOMmLOMtot

omminomomminomant

OnmLOMOMmNOOMOHtMOMOUO

Onm nomomm

0090000000000000000000

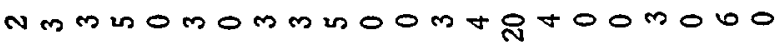

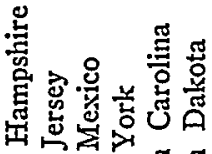

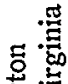

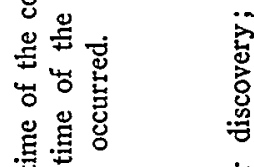

$\cong$ 兽

范若

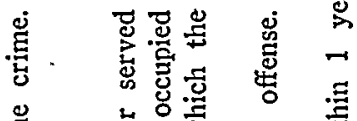

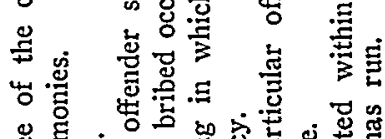

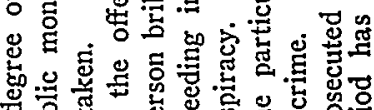
F

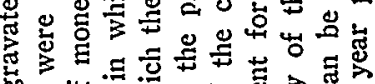

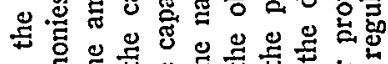

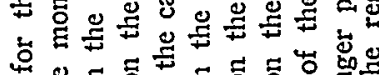

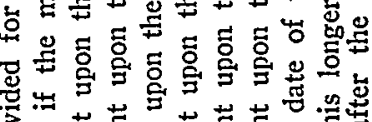

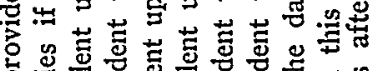

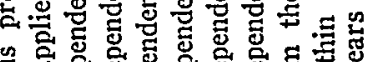

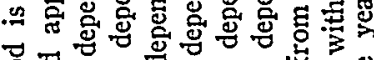
कृष

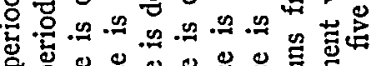

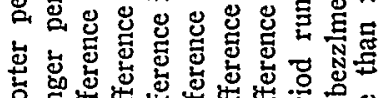

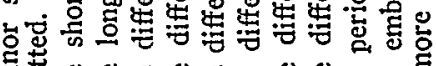

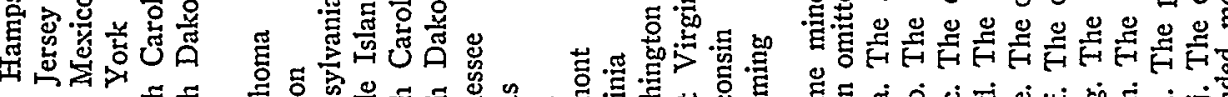

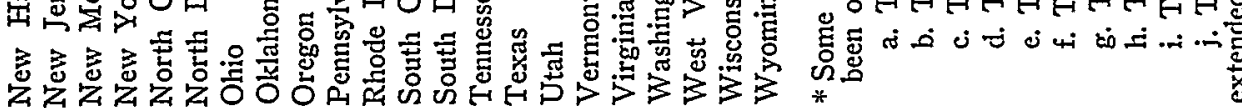

